\title{
Bcl-2-functionalized ultrasmall superparamagnetic iron oxide nanoparticles coated with amphiphilic polymer enhance the labeling efficiency of islets for detection by magnetic resonance imaging
}

\author{
This article was published in the following Dove Press journal: \\ International Journal of Nanomedicine \\ 15 October 2013 \\ Number of times this article has been viewed
}

\author{
Bin Yang' \\ Haolei Cai' \\ Wenjie Qin' \\ Bo Zhang' \\ Chuanxin Zhai ${ }^{2}$ \\ Biao Jiang ${ }^{3}$ \\ Yulian $\mathrm{Wu}^{\prime}$ \\ 'Department of Surgery, 2nd Affiliated \\ Hospital, School of Medicine, \\ Zhejiang University, Hangzhou, \\ People's Republic of China; ${ }^{2}$ State \\ Key Lab of Silicon Materials and \\ Department of Materials Science \\ and Engineering, Zhejiang University, \\ Hangzhou, People's Republic of \\ China; ${ }^{3}$ Department of Radiology, \\ 2nd Affiliated Hospital, School \\ of Medicine, Zhejiang University, \\ Hangzhou, People's Republic of China
}

\begin{abstract}
Based on their versatile, biocompatible properties, superparamagnetic iron oxide (SPIO) or ultrasmall superparamagnetic iron oxide (USPIO) nanoparticles are utilized for detecting and tracing cells or tumors in vivo. Here, we developed an innoxious and concise synthesis approach for a novel B-cell lymphoma (Bcl)-2 monoclonal antibody-functionalized USPIO nanoparticle coated with an amphiphilic polymer (carboxylated polyethylene glycol monooleyl ether [OE-PEG$\mathrm{COOH}]$ ). These nanoparticles can be effectively internalized by beta cells and label primary islet cells, at relatively low iron concentration. The biocompatibility and cytotoxicity of these products were investigated by comparison with the commercial USPIO product, FeraSpin ${ }^{\mathrm{TM}} \mathrm{S}$. We also assessed the safe dosage range of the product. Although some cases showed a hypointensity change at the site of transplant, a strong magnetic resonance imaging (MRI) was detectable by a clinical MRI scanner, at field strength of 3.0 Tesla, in vivo, and the iron deposition/attached in islets was confirmed by Prussian blue and immunohistochemistry staining. It is noteworthy that based on our synthesis approach, in future, we could exchange the Bcl-2 with other probes that would be more specific for the targeted cells and that would have better labeling specificity in vivo. The combined results point to the promising potential of the novel Bcl-2-functionalized PEG-USPIO as a molecular imaging agent for in vivo monitoring of islet cells or other cells.
\end{abstract}

Keywords: USPIO, MRI, beta cells, nanoparticle functionalization, islet transplantation, cell tracing

\section{Introduction}

In recent decades, superparamagnetic iron oxide (SPIO) or ultrasmall superparamagnetic iron oxide (USPIO) nanoparticles have been applied broadly to bioscience and clinical research for various purposes, including targeted drug delivery, gene delivery, and hyperthermia adjuvant therapy. ${ }^{1}$ The distinction between these two groups is made based on their diameter: USPIOs are smaller than $50 \mathrm{~nm}$, whilst SPIOs are larger than $50 \mathrm{~nm}^{2}$ They also have been conceded to be attractive magnetic resonance imaging (MRI) contrast agents, providing enhanced T2- and T2*-weighted contrast for the noninvasive detection and tracking of cells in vivo. For instance, ferumoxtran-10 (a commercial USPIO product approved by the US Food and Drug Administration [FDA] in 2005 ) is reported to be a viable imaging agent for pancreatic islet inflammation in type 1 A diabetes mellitus patients. ${ }^{3}$ However, since the FDA approval of the first generation commercial products, Feridex $^{\circledR}$ (Bayer Healthcare Pharmaceuticals Inc, Montville, NJ, USA) and Resovist ${ }^{\circledR}$ (Schering, Berlin-Wedding, Germany), ${ }^{4}$ manufacturing of these
Correspondence: Yulian Wu Department of Surgery, 2nd Affiliated Hospital, School of Medicine, Zhejiang University, 88 Jiefang Road, Zhejiang Province, Hangzhou 310009, People's Republic of China

Tel $+8657 \mid 87783602$

Fax +8657187784604

Email wuyulian@medmail.com.cn 
products was discontinued in 2008 and 2009 respectively, leaving a problematic lack of suitable clinical SPIO or USPIO agents that needs to be solved. During the last 5 years, numerous SPIO nanoparticles have been reported, with variations in surface coating, size, and target of ligand conjugation, ${ }^{5}$ but a suitable substitution has yet to be found.

It has been widely accepted that pancreatic beta cell replacement treatment, through islet cell transplantation, presents the best opportunity for healing type 1 diabetes mellitus and effectively prevents long-term serious complications. ${ }^{6}$ Meanwhile, with the development of nanotechnology and immune tolerance research, the progress of islet allotransplantation and xenotransplantation and the noninvasive visualization of transplanted pancreatic beta cells or islets have become a major focus. Using nanoscale contrast imaging agents, the direct and reliable labeling of beta cells before transplantation could be a valuable pathway for monitoring the islet transplant mass and function in conjunction with immune repressive therapy in vivo. To achieve this, the priority goals is to develop an ideal beta cell contrast agent with high labeling efficiency and possessing the following two properties: 1) the specific agents should be able to label the beta-cells accurately and to accumulate in or around the islets for cellular uptake, and 2) the agents should not affect the viability or function of the transplanted islet cells. Although a series of potential beta-cell-specific biomarkers have been investigated, including the sulfonylurea receptor, ${ }^{7}$ the presynaptic vesicular acetylcholine transporter, ${ }^{8}$ vesicular monoamine transporter $2,{ }^{9}$ and glucagon-like peptide $1,{ }^{10}$ most of these unfortunately failed to achieve specific targeting, and their labeling efficiency was unsatisfactory. Up to now, there has not been a report of a remarkable targeted USPIO with clinical application in beta cell- or islet-specific imaging. Another strategy for reaching the goal is to increase label efficiency using other approaches, including the use of nanoparticles functionalized with cell-penetrating peptides, ${ }^{11}$ transactivator (Tat) peptide sequences, ${ }^{12}$ or other techniques such as receptor-mediated endocytosis, magnetodendrimers, ${ }^{13}$ and transfection methods. ${ }^{14}$ However, some of these have obvious side effects, for example, the transfection agents have been shown to impair the chondrogenic differentiation of mesenchymal stem cells. ${ }^{15}$

B-cell lymphoma (Bcl)-2 is a member of a large family of apoptosis-regulating gene products that either facilitate cell survival (Bcl-2, Bcl-xL, and Bcl-w) or promote cell death (BAX, BAK, and BAD), and they function by selective protein-protein interaction. ${ }^{16}$ Previous observations have supported that the overexpression of $\mathrm{Bcl}-2$ in pancreatic islets ${ }^{17}$ or in the beta tumor cell 1 line ${ }^{18}$ protects these cells against apoptotic cell death. Bcl-2 may promote cell survival by interfering with the activation of the cytochrome c/apoptotic protease activating factor (Apaf)-1 pathway, through stabilization of the mitochondrial membrane. It has three benefits: first, the molecular weight of Bcl-2 is $26 \mathrm{kDa}$, which is relatively small compared with most other probes and has less cytotoxicity compared with cellpenetrating peptides, etc; second, Bcl-2 expression increases under higher iron $(\mathrm{Fe})$ concentrations, which is beneficial for enhancing labeling efficiency; and lastly, Bcl-2 is an integral membrane protein, localized to the outer mitochondrial membrane, endoplasmic reticulum, and nuclear envelope, which can be helpful in helping the nanoparticle to penetrate through cell membranes.

In the present study, we report a nontoxic synthesis method for producing water-soluble USPIO nanoparticles that began with hydrated ferric salts as Fe precursors (instead of noxious ferric acetylacetonate $\left.\left[\mathrm{Fe}(\mathrm{acac})_{3}\right]\right)$ and then coated these with amphiphilic polymers and then, functionalized them with Bcl-2 monoclonal antibody. We further investigated the labeling efficiency of these novel USPIOs to both primary rodent islets and beta cell lines (insulinoma [INS]-1 and beta-TC cells). Their cytotoxicity was also investigated in comparison with FeraSpin ${ }^{\mathrm{TM}} \mathrm{S}$ (Miltenyi Biotec, Bergisch Gladbach, Germany), and magnetic resonance imaging (MRI) was performed for monitoring the nanoparticle labeled islets in vivo, in ICR mice.

\section{Material and methods Synthesis of polyethylene glycol-coated ultrasmall superparamagnetic Fe oxide nanoparticles}

Polyethylene glycol (PEG)-coated USPIO (PEG-USPIO) nanoparticles were synthesized based on the procedure of Liang et al, ${ }^{19}$ with some modifications. Briefly, $0.556 \mathrm{~g}$ $\mathrm{FeSO}_{4} \cdot 7 \mathrm{H}_{2} \mathrm{O}$ was first dissolved in $20 \mathrm{~mL}$ deionized (DI) water $\left(0.002 \mathrm{~mol} \mathrm{Fe}^{2+}\right)$, which was designated as solvent A. Next, $1 \mathrm{~g}$ $\mathrm{NaOH}$ was dissolved in $10 \mathrm{~mL}$ ethyl alcohol followed with $10 \mathrm{~mL}$ oleic acid and mixed well, in room temperature, and this was designated as solvent $\mathrm{B}$. Then, solvent A was transferred into $\mathrm{B}$ and dissolved. The mixture was heated to $180^{\circ} \mathrm{C}$ in a $50 \mathrm{~mL}$ autoclave for 10 hours and cooled down to room temperature. The product, the USPIO nanoparticle residue, was washed with ethyl alcohol and centrifuged at 2,000 rpm for 5 minutes. After discarding the supernatant, the precipitant was spun and washed with cyclohexane and ethyl alcohol (1:5 $\mathrm{v} / \mathrm{v}$ ) for a total of three times. To improve the water solubility, $0.5 \mathrm{~g}$ of the USPIO nanoparticles and $200 \mathrm{mg}$ PEG monooleyl 
ether (OE-PEG-OH) (molecular weight $[\mathrm{MW}] \approx 2,500$; Tokyo Chemical Industry Co, Ltd, Tokyo, Japan) were dissolved in $20 \mathrm{~mL}$ toluene, and then the solvent was evaporated by rotary evaporator at $40^{\circ} \mathrm{C}$ for 20 minutes (the optimized ratio of nanoparticles and OE-PEG-OH had been determined by parallel tests [data not shown]). Finally, the PEG-USPIO was resuspended in DI water and centrifuged at 4,000 rpm for 10 minutes and the supernatant collected. Before being cultured with cells in vitro, the PEG-USPIO was sterilized with 20,000 Gy irradiation. The physiochemical properties of PEGUSPIO were characterized by vibrating sample magnetometer (VSM; MPMS XL-5, Quantum Design, Inc., San Diego, CA, USA), dynamic light scattering (DLS; Zetasizer 3000HSa, Malvern Instruments, Malvern, Worcestershire, UK) and transmission electron microscope (TEM; JEM-1230, JEOL, Tokyo, Japan) examinations.

\section{Carboxylation of the amphiphilic polymer coating and binding of $\mathrm{Bcl}-2$ antibody}

For advanced conjugation of the probe to the nanoparticle, the terminal hydroxyl of the amphiphilic polymer (OEPEG-OH) needed to be modified into a carboxyl group (OEPEG-COOH). The procedure was as follows: OE-PEG-OH was added to a solution consisting of $1 \mathrm{M}$ chloroacetic acid in $3 \mathrm{M} \mathrm{NaOH}$, to a final concentration of OE-PEG-OH of $20 \mathrm{mg} / \mathrm{mL}$. The compound was well dissolved and reacted for 70 minutes, at room temperature, with magnetic stirring. The reaction was terminated by adding $4 \mathrm{mg} / \mathrm{mL}$ of solid $\mathrm{NaH}_{2} \mathrm{PO}_{4}$ and adjusting the $\mathrm{PH}$ to neutral with $6 \mathrm{~N} \mathrm{HCl}$. The excess reactants were removed by dialysis $(1,000 \mathrm{MW}$; Spectrum Laboratories, Inc., Rancho Dominguez, CA, USA) for 2 days. The carboxylation of OE-PEG-OH was assessed and confirmed by nuclear magnetic resonance (NMR).

Bcl-2 monoclonal antibody was purchased from Santa Cruz Biotechnology (Mouse anti-Bcl-2 antibody, sc-7382; Santa Cruz Biotechnology Inc, Dallas, TX, USA). COOHPEG-USPIO, was produced by a similar procedure as PEG-USPIO by evaporating the mixed solvent of $\mathrm{COOH}-$ PEG-OE and USPIO, and collection following centrifugation. The functionalization of the COOH-PEG-USPIO with Bcl-2 was achieved by the N-hydroxysuccinimide (NHS)/ ethyl(diethylaminopropyl carbodiimide (EDC) method. ${ }^{10}$ Briefly, $2.5 \mu \mathrm{mol}$ EDC hydrochloride $(\mathrm{EDC} \cdot \mathrm{HCl})$ and 6.25 $\mu \mathrm{mol}$ sulfo-NHS were mixed in $950 \mu \mathrm{L}$ of $0.01 \mathrm{M}$ phosphatebuffered saline (PBS); then, $1 \mathrm{mg}$ COOH-PEG-USPIO was added in, and all the ingredients were incubated, at room temperature, on a rotating shaker for 15 minutes. After the carboxyl groups of the nanoparticles were thus activated, the Bcl-2 antibody was added (200 $\mu \mathrm{g}$ in $1 \mathrm{~mL}$ PBS $)$ and incubated for 24 hours on a rotating shaker, at room temperature. Then, Bcl-2-USPIO was isolated and purified magnetically to remove excess residues.

\section{Cell culture and islet cell isolation}

Beta-TC-6 cells (The Cell Bank of Type Culture Collection of Chinese Academy of Sciences, Shanghai, People's Republic of China), a mouse insulinoma beta cell line, were cultured in high-glucose Dulbecco's Modified Eagle's Medium (DMEM) supplemented with $15 \%$ fetal bovine serum (FBS), $100 \mathrm{IU} /$ $\mathrm{mL}$ penicillin, and $100 \mu \mathrm{g} / \mathrm{mL}$ streptomycin, at $37^{\circ} \mathrm{C}$ in a humidified atmosphere $\left(5 \% \mathrm{CO}_{2}\right)$. Rat INS-1 cells (The Cell Bank of Type Culture Collection of Chinese Academy of Sciences) were grown in regular Roswell Park Memorial Institute (RPMI)-1640 medium supplemented with 10\% FBS, $100 \mathrm{IU} / \mathrm{mL}$ penicillin, and $100 \mu \mathrm{g} / \mathrm{mL}$ streptomycin, at $37^{\circ} \mathrm{C}$ in a humid atmosphere $\left(5 \% \mathrm{CO}_{2}\right)$.

The islet cells were harvested by methods described previously with, some modification. ${ }^{20}$ Briefly, $4 \mathrm{~mL}$ of collagenase, Type IV (C5138; Sigma-Aldrich Corp, St Louis, MO, USA) $(2 \mathrm{mg} / \mathrm{mL})$ was injected into the common bile duct of 5- to 6-week-old ICR mice (Medical Institute Animal Center of Zhejiang Chinese Medical University, Hangzhou, People's Republic of China). The distended pancreas was isolated and put into a $50 \mathrm{~mL}$ conical tube containing an additional $0.5 \mathrm{~mL}$ of collagenase IV. Then the top of the tube was closed, wrapped with Parafilm ${ }^{\circledR}$ (Sigma-Aldrich), placed in a water bath at $37^{\circ} \mathrm{C}$ for 8 minutes, and then shaken for 24 minutes (one tube for two pancreases). The derived tissues were purified by Ficoll ${ }^{\mathrm{TM}}$ gradient centrifugation (Ficoll PM400, catalogue number; GE Healthcare, Little Chalfont, Buckinghamshire, UK). The islet cells were cultured overnight in RPMI 1640 containing 10\% FBS, in plates.

All the animal experiments were executed according to the ethical guidelines of the Animal Experimentation Committee in the College of Medicine, Zhejiang University, Hangzhou, People's Republic of China.

\section{In vitro beta cell labeling and Prussian blue staining}

The INS-1 cells were cultured with a complete medium containing various concentrations of PEG-USPIO (equivalent to $0,10,20,30,40$, and $50 \mu \mathrm{g} / \mathrm{mL}$ of Fe concentration respectively) for 24 hours; as control groups, INS-1 cells were incubated with FeraSpin ${ }^{\mathrm{TM}} \mathrm{S}$ at the same Fe concentrations. After that, the culture medium was discarded, and the cells were washed with PBS for three times gently. Next, these labeled cells were incubated with Pearls' reagent ( $2 \%$ potassium ferrocyanide/4\% $\mathrm{HCl}: 1 / 1$ ) for 10 minutes. 
Subsequently, after washing away the Pearls' reagent with PBS for three times, the nanoparticle accumulation in the INS-1 cells was observed using a microscope (CKX31, Olympus Corporation, Tokyo, Japan).

\section{Quantification of intracellular Fe content and cytotoxicity assay in vitro}

The intracellular Fe concentrations were quantified by inductively coupled plasma atomic absorption spectroscopy (ICPAAS) (180-50; Hitachi Ltd, Tokyo, Japan). The labeled cell pellet was dissolved in $37 \% \mathrm{HCl}$ solution at $70^{\circ} \mathrm{C}-80^{\circ} \mathrm{C}$ for 30 minutes. The samples were diluted to final Fe concentrations of $1.0-4.0 \mathrm{mg} / \mathrm{L}$ for further testing.

For the cell viability assay, the INS-1 cells were seeded in 96-well tissue culture plates, at a density of $5 \times 10^{4}$ cells/ well, labeling the cells with PEG-USPIO for 24 hours (Fe concentration: $10,20,30,40$, and $50 \mu \mathrm{g} / \mathrm{mL}$, respectively). Then, 20 mL 3-(4,5-Dimethylthiazol-2-yl)-2,5-diphenyltetrazolium bromide (MTT) solution was added to each well. After 4 hours of incubation, the supernatant was removed, and $150 \mathrm{~mL}$ of dimethyl sulfoxide (DMSO) was added to each well. The plates were shaken for 10 minutes, and the optical density was measured by an enzyme-linked immunosorbent assay (ELISA) reader (ELx800 Absorbance Microplate Reader; Bio-Tek Instruments, Inc, Winooski, VT, USA), at a wavelength of $570 \mathrm{~nm}$. This procedure was repeated for at least three subculture passages.

For the apoptosis/cell death assessment, INS-1 cells $\left(3 \times 10^{6}\right.$ cells/well, in 6-well tissue culture plates) were labeled with PEG-USPIO for 24 hours (at Fe concentration: 10, 20, $30,40,50 \mu \mathrm{g} / \mathrm{mL}$, respectively) and then gently washed with PBS for three times. The apoptosis of the labeled cells was analyzed by flow cytometry (FCM) (BD FACSCalibur, BD Biosciences Pharmingen, San Diego, CA, USA) after incubation with annexin $\mathrm{V}$ and propidium iodide (PI) (both $5 \mu \mathrm{g} / \mathrm{mL}$ ) (Annexin V/PI apoptosis detection kit, m3021-2, Molecular Biology and Chemical Company [Mbchem], Shanghai, People's Republic of China), at room temperature, in a dark place, for 15 minutes.

\section{Glucose-stimulated insulin release assay}

The beta-TC-6 cells, labeled with the various Fe concentrations of PEG-USPIO, were incubated in Krebs-Ringer Bicarbonate Buffer (KRBB) medium $\left(1 \times 10^{5}\right.$ cells/well, in 24-well culture plates) supplemented with $1 \%$ bovine serum albumin (BSA), for 45 minutes. Then, the media were removed, and the cells were incubated with either low-glucose KRBB medium (containing $3.3 \mathrm{mM}$ D-glucose) or highglucose (containing 16.5 mM D-glucose) KRBB medium, supplemented with $1 \% \mathrm{BSA}$ at $37^{\circ} \mathrm{C}$ for 45 minutes, after which $200 \mu \mathrm{L}$ of supernatant from each sample was collected and analyzed for rodent insulin content using a radioimmunoassay kit (S10930046, Beijing North Institute of Biological Technology, Beijing, People's Republic of China). All the groups were detected for three times.

\section{Bcl-2 expression assay in INS-I cells}

For the Bcl-2 expression assay, the INS-1 cells were seeded in 6-well plates and cultured with increasing concentrations of PEG-USPIO (Fe concentration: 0, 10, 20, and $30 \mu \mathrm{g} / \mathrm{mL}$ ) for 24 hours. All the cells were washed with PBS and collected for Western blot assay. Briefly, the labeled cells were lysed with lysis buffer containing $10 \mathrm{mM}$ Tris aminomethane (Tris) (Ph 7.4), $100 \mathrm{mM} \mathrm{NaCl}, 1 \mathrm{mM}$ ethylenediaminetetraacetic acid (EDTA), $1 \mathrm{mM}$ ethylene glycol tetraacetic acid (EGTA), $1 \mathrm{mM}$ $\mathrm{NaF}, 0.1 \%$ sodium dodecyl sulfate (SDS), $0.5 \%$ deoxycholate, $10 \%$ glycerol, $1 \%$ Triton $^{\circledR} \mathrm{X}-100,20 \mathrm{mM} \mathrm{Na}_{4} \mathrm{P}_{2} \mathrm{O}_{7}, 5 \mathrm{mg} / \mathrm{mL}$ aprotinin, $5 \mathrm{mg} / \mathrm{mL}$ leupeptin, $2 \mathrm{mM} \mathrm{Na}_{3} \mathrm{VO}_{4}$, and $1 \mathrm{mM}$ phenylmethylsulfonyl fluoride (PMSF). The protein content in each fraction was quantified using a bicinchoninic acid protein kit (Pierce ${ }^{\mathrm{TM}}$ BCA Protein Assay Kit; Thermo Fisher Scientific Inc, Waltham, MA, USA). Equal amounts of protein were subjected to SDS-polyacrylamide gel electrophoresis (PAGE) and transferred onto polyvinylidene fluoride (PVDF) membranes. The membranes were blocked in 5\% milk and incubated with the primary antibody (ZS-4920, rabbit antiBcl-2 (N-19), ZSGB-BIO, Beijing, People's Republic of China) overnight. A horseradish peroxidase (HRP)-conjugated secondary antibody (7074P2, anti-rabbit IgG; Cell Signaling Technology, Beijing, People's Republic of China) was incubated with the membranes at room temperature for 1 hour. After washing with $0.1 \%$ Tween $^{\circledR} 20$, the immunoreactive bands were observed with an enhanced chemiluminescence (ECL) Western blot detection kit (20-500-120, EZ-ECL kit, Biological Industries, Kibbutz Beit-Haemek, Israel). All the samples were examined in three separate experiments.

\section{In vitro MRI of PEG-USPIO and $\mathrm{Bcl}$-2-USPIO}

The different Fe concentrations of PEG-USPIO or Bcl-2-USPIO were aspirated into Eppendorf tubes and diluted with DI water. All samples were placed in a water-containing plastic container to avoid having susceptibility artifacts from the surrounding air in the scans. T2-weighted fast spin echo sequences ([repetition time/ echo time] TR/TE $=4,000 / 80 \mathrm{~ms}$ ) and T2 map sequences (TR/ $\mathrm{TE}=2,000 / 15,30,45$, and $60 \mathrm{~ms}$ ) were used. The slice thickness was $1.0 \mathrm{~mm}$ with a $0.1 \mathrm{~mm}$ gap, and the field of view (FOV) was $10 \times 1.2 \mathrm{~cm}^{2}$, and regions of interest $(\mathrm{ROI})=9.2 \mathrm{~mm}^{2}$. 


\section{Immunofluorescence of Bcl-2-USPIO in INS-I cells}

The INS-1 cells were seeded in 6-well tissue culture plates $\left(3 \times 10^{6}\right.$ cells $/$ well, prepaved with cell slides, diameter $=25 \mathrm{~mm}$ ). Functionalized or nonfunctionalized PEG-USPIO was incubated with INS- 1 cells, at various concentrations $(10,30$, and $50 \mu \mathrm{g} / \mathrm{mL} \mathrm{Fe}$ concentration, respectively), for 24 hours. All subsequent steps were followed by a three-time 3-minute wash in PBS. The cells were fixed with alcohol and acetone $\left(1: 1\right.$ in volume) at $4^{\circ} \mathrm{C}$ for 15 minutes, and then, $0.5 \%$ TritonX-100/PBS [v/v] was added at room temperature for 30 minutes. Then the slides were incubated with goat anti-mouse IgG (Goat Anti-Mouse IgG-FITC: SC-2010; Santa Cruz Biotechnology) for 1 hour. The nuclei were stained with 4',6-diamidino-2-phenylindole (DAPI) (Life Technologies, Carlsbad, CA, USA). Observation and image acquisition were performed with a confocal microscope (LSM 710 system, Carl Zeiss Meditec, Jena, Germany).

\section{In vitro Prussian blue staining and in vivo immunohistochemistry of Bcl-2-USPIO- labeled primary islet cells}

The primary islet cells that were isolated from the ICR mice, as described above, were labeled with Bcl-2-USPIO (10 or $30 \mu \mathrm{g} / \mathrm{mL}$ Fe concentration) and cultured in complete RPMI 1640 medium for 24 hours. After incubation, the islet cells were washed with PBS three times and incubated with Pearls' reagent for 10 minutes. Then, the Pearls' reagent was washed away with PBS for three times, and the nanoparticle accumulation was observed using a microscope (CKX31, Olympus Corporation).

Male ICR mice, 5-6-weeks-old, were used for the islet cell transplantation. Bcl-2-USPIO-labeled islets (Fe concentration: 10 or $30 \mu \mathrm{g} / \mathrm{mL}$ ) were then transplanted into the left renal capsule of the ICR mice $(n=3)$ with standard procedures. At 24 hours post-transplantation, the mice were sacrificed, and the left kidneys were dissected, fixed with $4 \%$ paraformaldehyde and embedded in paraffin wax. The kidney sections were stained with anti-insulin antibody (H-86, SC-9168, Santa Cruz Biotechnology Inc, Dallas, TX, USA), followed with hematoxylin and eosin (H\&E) stain and meanwhile, serial sections were stained by Prussian blue (PB), followed with H\&E stain, as control, to observe the existence/accumulation of Fe. Standard protocols were followed for the stains performed in this study. ${ }^{21}$

\section{In vivo $\mathrm{MRI}$ of $\mathrm{Bcl}-2-U S P I O-l a b e l e d$ islets}

Purified islet cells were labeled with Bcl-2-USPIO according to the previous procedures ( 10 or $30 \mu \mathrm{g} / \mathrm{mL}$, respectively). Approximately 150 labeled islet cell clusters were resuspended in $20 \mu \mathrm{L}$ PBS and were transplanted under the left renal capsule of anesthetized ICR mice ( $\mathrm{n}=3$ ). MRI scanning was performed post-transplantation (on day 1,7,14,21, and 35), using a clinical MRI scanner (Signa HDxt 3.OT, GE Healthcare). A special mouse coil (with max bore diameter of $13 \mathrm{~cm}$ ) adapted for the MRI scanner, available from GE Healthcare, was used. A series of T2-weighted images were acquired using T2-weighted fast spin echo sequences (TR/TE $=4,000 / 80 \mathrm{~ms})$. The spatial resolution parameters were as follows: $\mathrm{FOV}=6 \times 4.2 \mathrm{~cm}$, matrix size $=288 \times 256$, slice thickness $/$ gap $=1.0 \mathrm{~mm} / 0.1 \mathrm{~mm}$, scan time $=200 \mathrm{~s}$, and number of excitations $(\mathrm{NEX})=4$.

\section{Results \\ Synthesis and characterization of PEG-USPIO}

The nanoparticles were uniformly distributed (Figure 1A), and the core size was 4-10 nm (Figure 1B). Figure 1C reveals the morphology of PEG-USPIO after the amphiphilic polymer coating, by TEM. Figure 1D shows that the saturation magnetization intensity of our PEG-USPIO was nearly $38 \mathrm{emu} / \mathrm{g}$, indicating it had good superparamagnetic behavior. The DLS results show that the average hydrodynamic size of the PEG-USPIO nanoparticles was around $28 \mathrm{~nm}$ (Figure 1E). We noted that the length of the amphiphilic polymers (approximate 50 carbon chains) was quite an important parameter to the hydrodynamic size - if the carbon chain was too short, the amphiphilic properties of the nanoparticles became weak, causing worse water-solubility, while contrarily, the hydrodynamic size was much larger.

\section{Amphiphilic polymer carboxylation and $\mathrm{Bcl}-2$ binding}

As the carboxyl and amino groups are the most common and useful groups for chemical binding, we modified the terminal hydroxyl of the amphiphilic polymer (OE-PEG-OH) into a carboxyl group (OE-PEG-COOH) by an oxidizing reaction. The result was confirmed by the ${ }^{13} \mathrm{C}$-NMR spectra, in which the terminal carboxyl peak (at $163 \mathrm{ppm}$ ) was distinctly presented after the modification (Figure 1F). The modified $\mathrm{COOH}$ group was activated later to bind the Bcl-2.

The Bcl-2 monoclonal antibody was combined with the as-prepared OE-PEG-COOH by the NHS-EDC method and subsequently coated on the Fe core. The successful binding of Bcl-2 was confirmed by following immunofluorescent assay.

\section{INS-I cell labeling efficiency of PEG-USPIO in vitro}

Our novel PEG-USPIO proved to be better endocytosed by INS-1 cells compared with the commercial product 

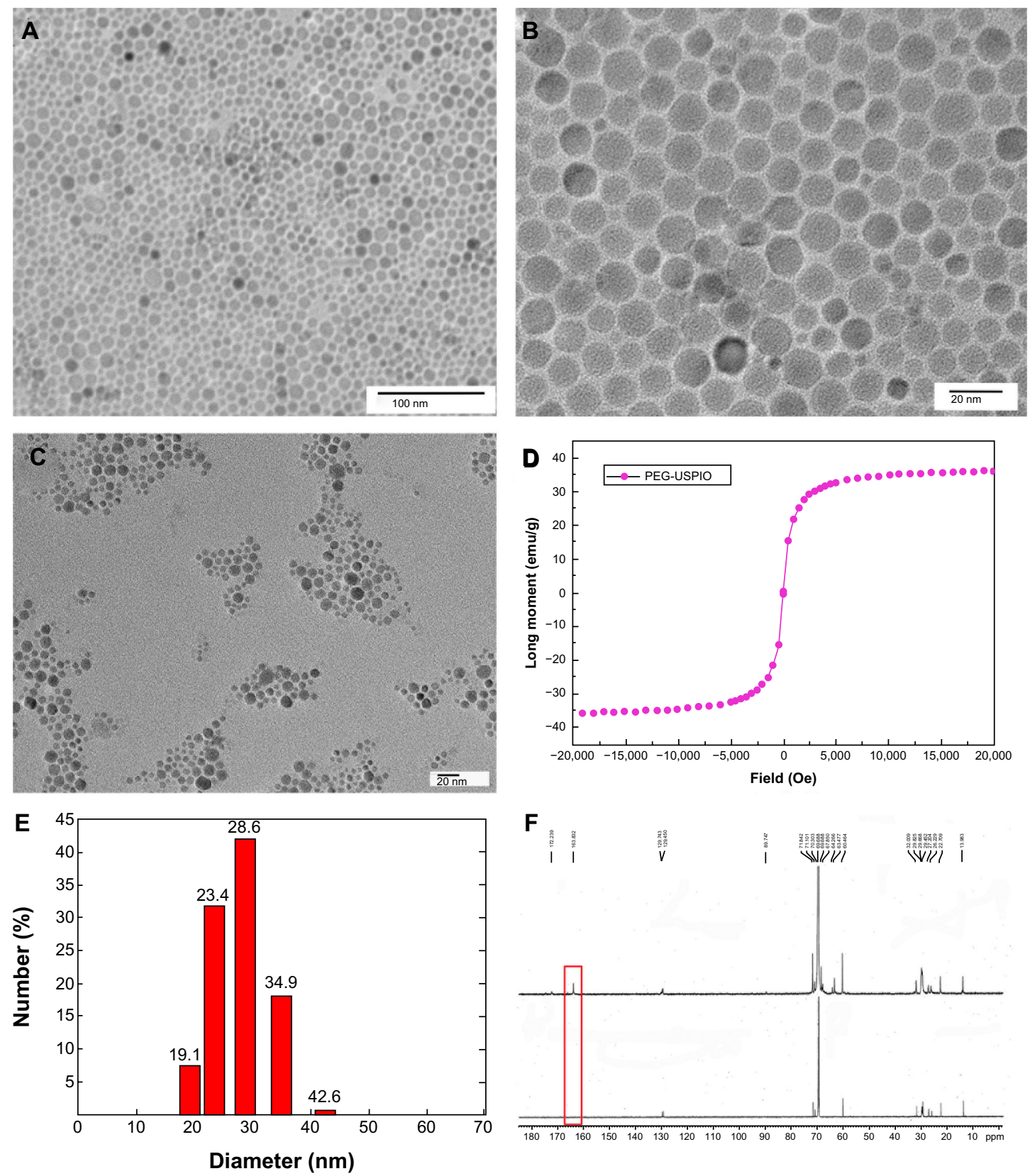

Figure I The morphological and physicochemical properties of the PEG-USPIO were investigated.

Notes: Images $(\mathbf{A})$ and $(\mathbf{B})$ revealed the size of the iron core (bar $=100 \mathrm{~nm}$ and $=20 \mathrm{~nm}$, respectively). (C) TEM picture of the PEG-USPIO (bar $=20 \mathrm{~nm}$ ). (D) The magnetic property of the PEG-USPIO was assessed by the MPMS. (E) DLS assay demonstrates that the hydrodynamic size of the nanoparticle was approximately $28 \mathrm{~nm}$. (F) The $\mathrm{C}^{13} \mathrm{NMR}$ spectrum of PEG-OH (below) and PEG-COOH (above). The presence of a carboxyl group peak at 163.8 ppm (red frame) indicates the carboxylation of the terminal hydroxyl. Abbreviations: DLS, dynamic light scattering; MPMS, magnetic property measurement system; NMR, nuclear magnetic resonance; PEG-USPIO, polyethylene glycol-coated ultrasmall superparamagnetic iron oxide; TEM, transmission electron microscope.

FeraSpin ${ }^{\mathrm{TM}} \mathrm{S}$ (mean particle size $\left.=20-30 \mathrm{~nm}\right)$. Figure 2 shows that with the increase of the Fe concentration (from $10 \mu \mathrm{g} /$ $\mathrm{mL}$ to $50 \mu \mathrm{g} / \mathrm{mL}$ ), more PEG-USPIOs were deposited in the INS-1 cells. From these pictures, we also notice that PEGUSPIO labeled the INS-1 cells much more evenly than did FeraSpin ${ }^{\mathrm{TM}} \mathrm{S}$, which demonstrates the strong dispersibility of our product. As Figure 3A presents, the intracellular Fe content assays also verified that as the Fe concentration increased progressively, more USPIOs were aggregated in the cells.

\section{Cytotoxicity assessment of PEG-USPIO and $\mathrm{BCl}-2$ expression assessment of INS-I cells}

For in vivo islet cell tracking, the biological effects of the contrast agents should be investigated as a top priority. 

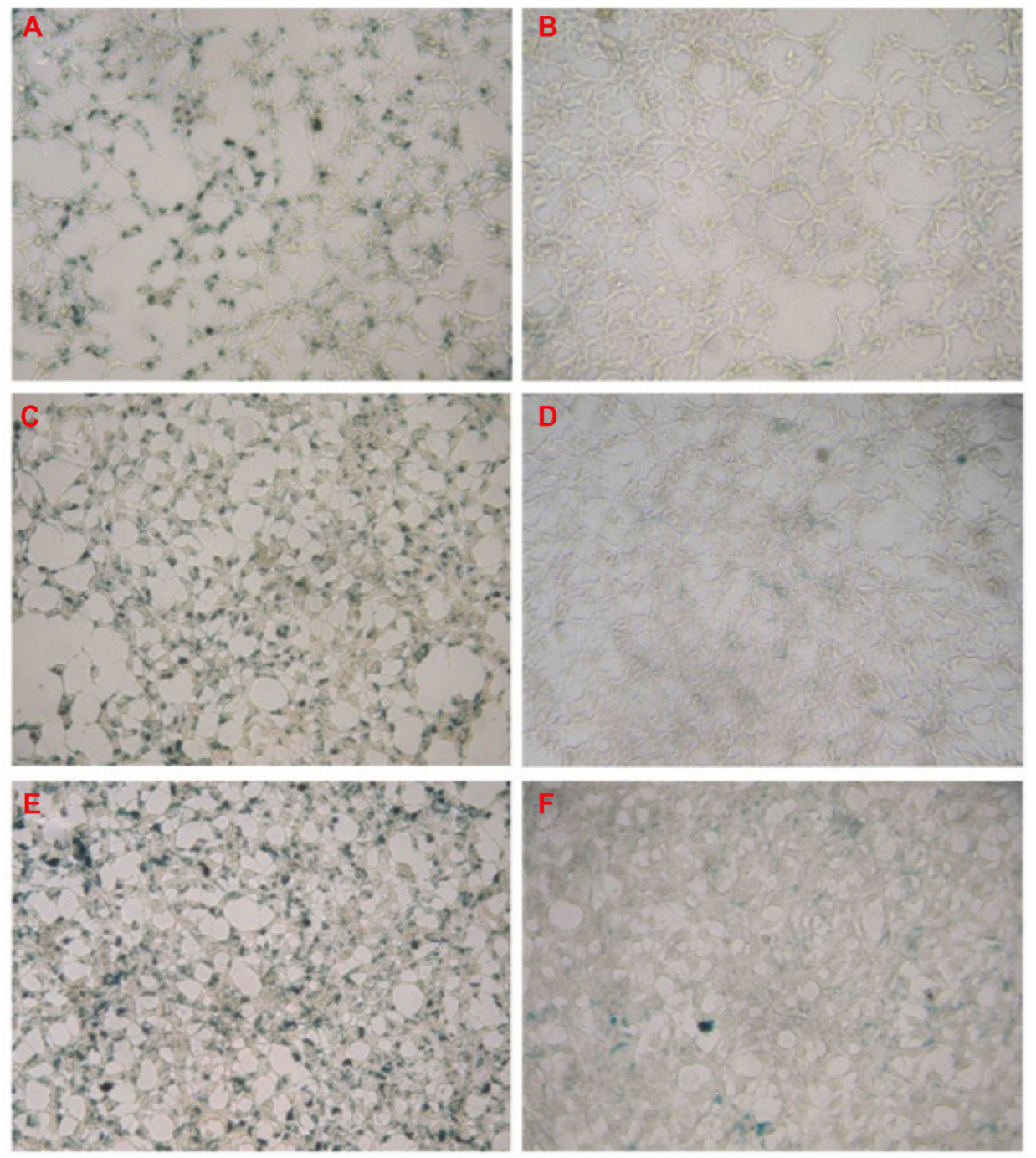

Figure 2 INS-I cells were cultured with PEG-USPIO (A, C, and E) or FeraSpin ${ }^{\text {TM }}$ S (B, D, and F) at different concentrations for 24 hours and subsequently stained with Prussian blue.

Notes: The iron concentration was: $10 \mu \mathrm{g} / \mathrm{mL}$ for (A and B); $30 \mu \mathrm{g} / \mathrm{mL}$ for (C and D); and $50 \mu \mathrm{g} / \mathrm{mL}$ for (E and F).

Abbreviations: INS, insulinoma; PEG-USPIO, polyethylene glycol-coated ultrasmall superparamagnetic iron oxide.

From the variation of cell viability of the PEG-USPIOlabeled INS-1 cells, as demonstrated by the MTT assay results, we can conclude that the PEG-USPIO had less cytotoxicity until the Fe concentration exceeded $30 \mu \mathrm{g} / \mathrm{mL}$ (Figure 3B). The glucose-stimulated insulin release test confirmed the nanoparticles did not harm the function of the islet/beta-cells, at low Fe concentration (Figure 3C). The beta-TC cells produced sufficient insulin on stimulation with high glucose while the Fe concentration was below $30 \mu \mathrm{g} / \mathrm{mL}$, however, over this dosage, the insulin secretion reaction became progressively weaker as the concentration increased. The FCM results also reveals that the percentage of dead cells plus apoptotic cells increased rapidly when the Fe concentration exceeded $30 \mu \mathrm{g} / \mathrm{mL}$ (Figure 3D-I). All these results demonstrate that $30 \mu \mathrm{g} / \mathrm{mL}$ was the upper limit of safe dosage for our USPIOs with regards to guaranteed cell function and viability.

The Bcl-2 expression of INS-1 cells was assessed with pretreated PEG-USPIO for 24 hours (Figure 3J), and the gray density ratio of $\mathrm{Bcl}-2$ and beta-actin (the control) was also calculated, as presented by Figure $3 \mathrm{~K}$. We concluded that with increasing Fe concentration, the Bcl-2 expression of INS-1 cells showed a gradual upward trend.

\section{MRI of PEG-USPIO or Bcl-2-USPIO and immunofluorescence of USPIO-labeled INS-I cells}

The T2-weighted MR images of PEG-USPIO and Bcl-2USPIO with increasing Fe concentrations (Figure 4A) displayed hypointense signals when the Fe concentration 
A

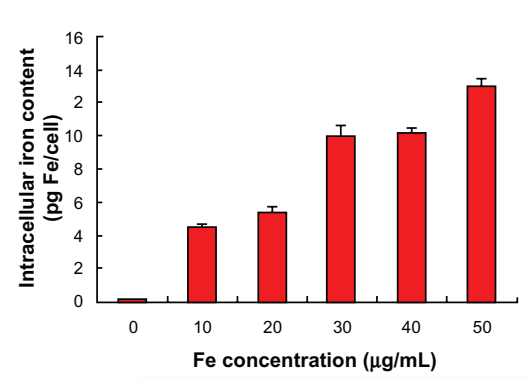

D

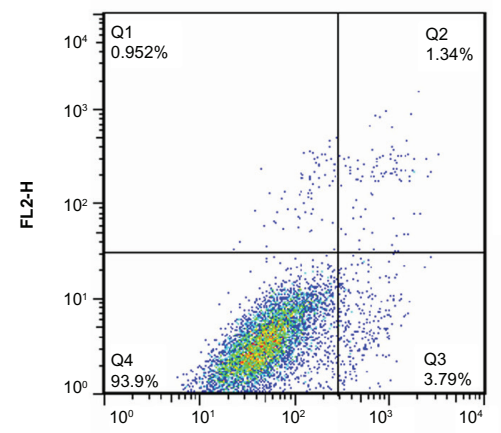

G

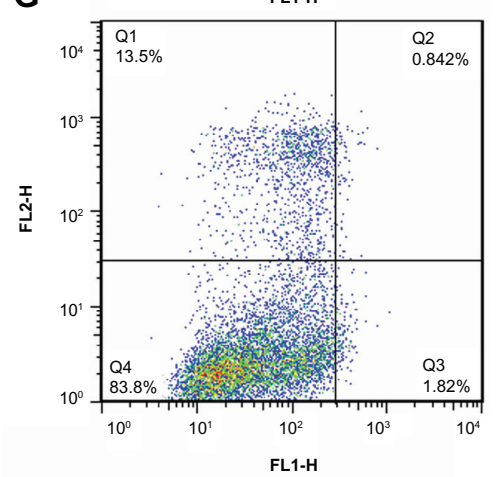

J

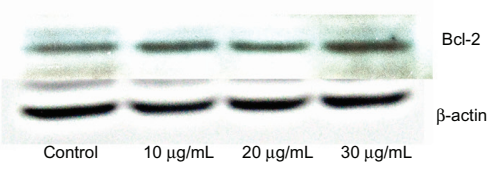

J
B

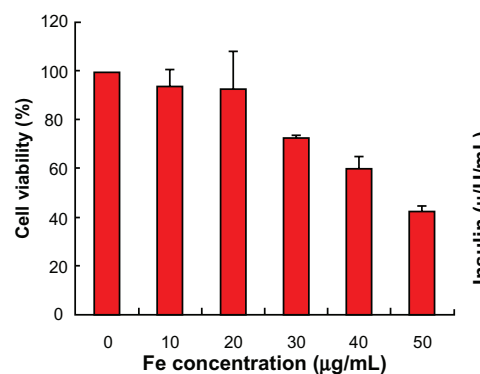

E

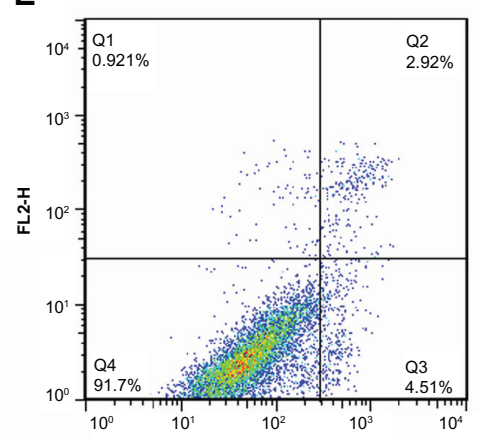

H

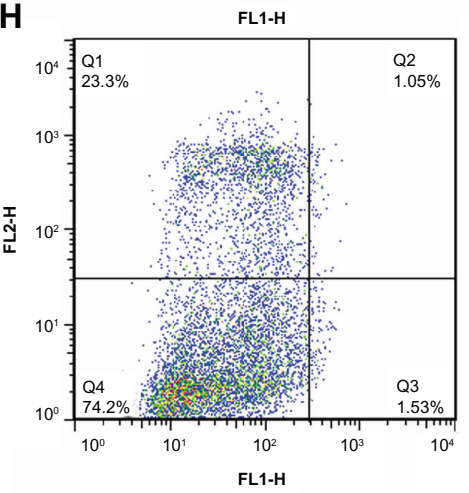

C

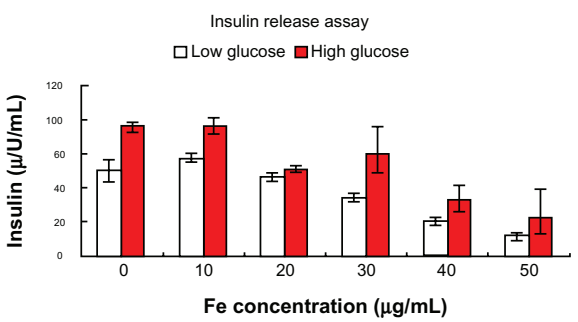

$\mathbf{F}$

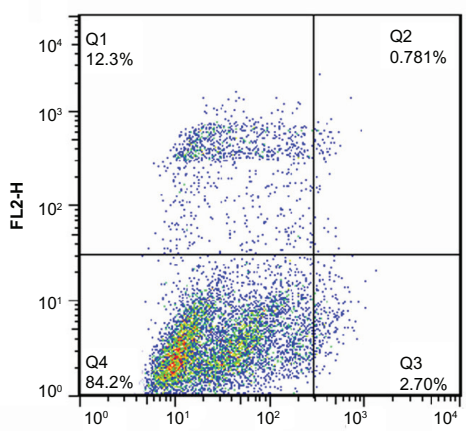

I

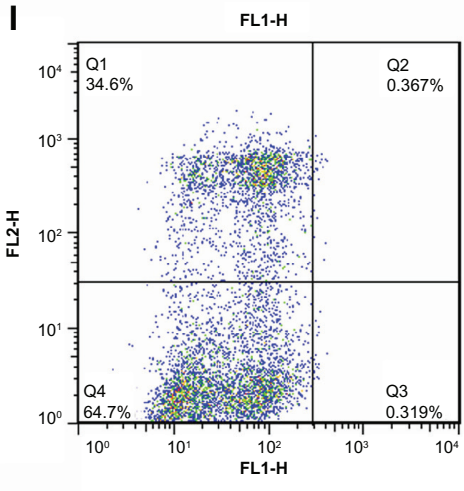

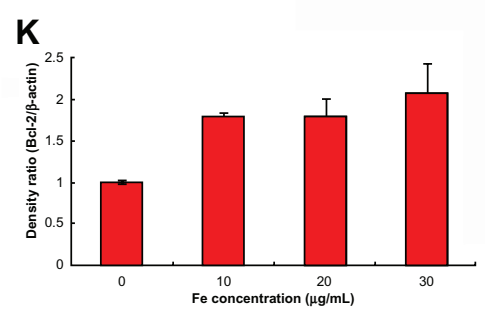

Figure 3 The intracellular iron content of the INS-I cells after 24 hours of preculture with PEG-USPIO at various iron concentrations (A). The cell viability assay of the INSI cells, by MTT (B). The insulin release assay of the beta-TC cells pretreated with PEG-USPIO for 24 hours (C). The flow cytometry results of the INS-I cells precultured with PEG-USPIO at different iron concentrations, for 24 hours: the control (D); $10 \mu \mathrm{g} / \mathrm{mL}$ (E); $20 \mu \mathrm{g} / \mathrm{mL}$ (F); $30 \mu \mathrm{g} / \mathrm{mL}$ (G); $40 \mu \mathrm{g} / \mathrm{mL}$ (H); and 50 $\mu \mathrm{g} / \mathrm{mL}$ (I). Western blot results of INS-I cells after 24 hours of nanoparticle coculture. The Bcl-2 expression increased slightly associated with the increasing iron concentration (J). The gray density ratio of $\mathrm{Bcl}-2$ and $\beta$-actin (the control) (K).

Abbreviations: Bcl, B-cell lymphoma; FE, iron; INS, insulinoma; MTT, 3-(4,5-Dimethylthiazol-2-yl)-2,5-diphenyltetrazolium bromide; PEG-USPIO, polyethylene glycol-coated ultrasmall superparamagnetic iron oxide.

exceeded $10 \mu \mathrm{g} / \mathrm{mL}$. This was consistent with our following in vivo results. The magnetic property of Bcl-2-USPIO was lower than that of PEG-USPIO, due to the connection of the antibody (Figure 4B). The thicker coating of the same Fe core influenced the spin speed of the USPIO in the magnetic field, inducing a lower paramagnetic property.

The immunofluorescence picture (Figure 5) indicated that more Bcl-2-USPIOs were internalized by the INS-1 cells compared with untagged USPIOs. We believe the Bcl-2 


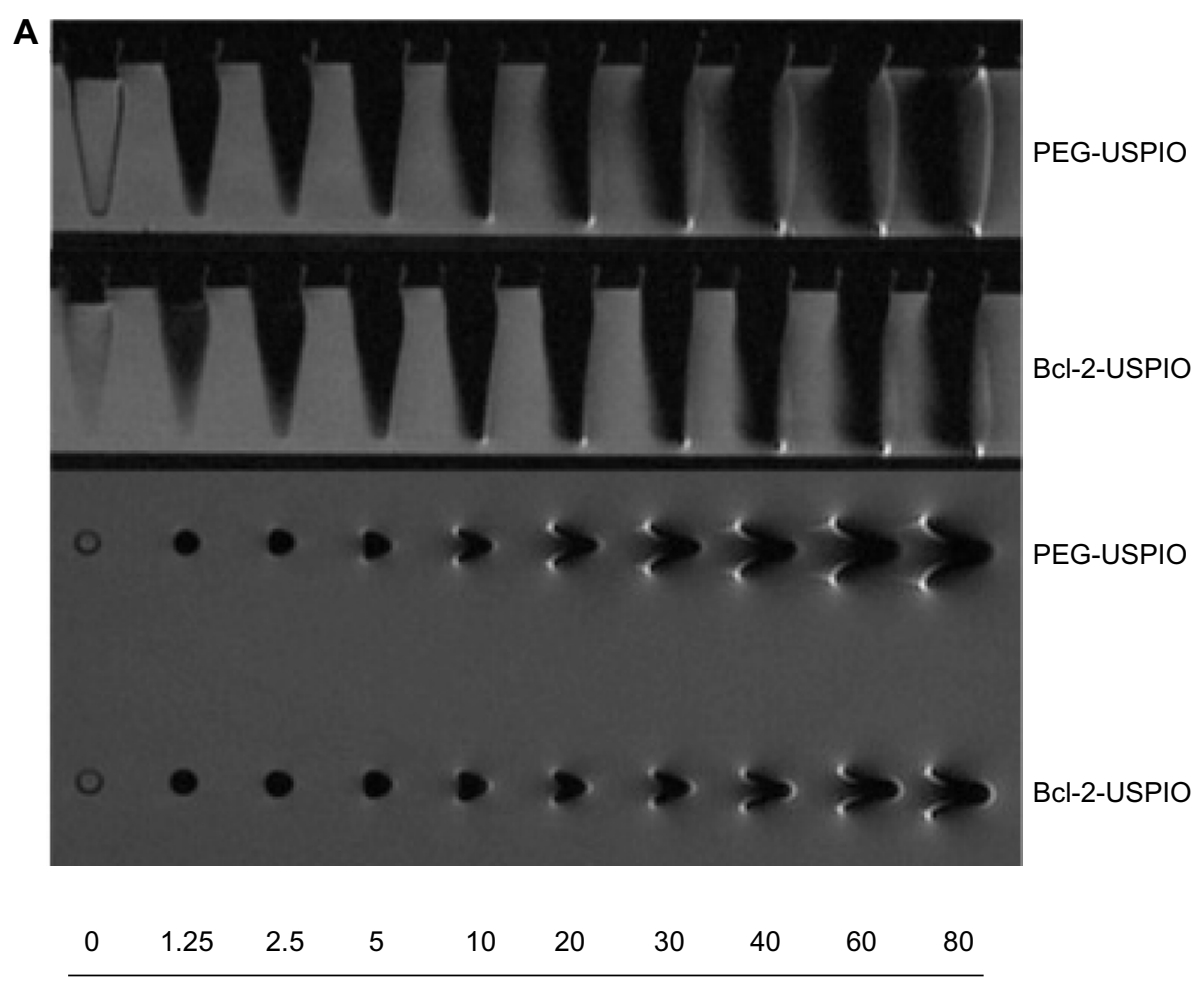

Fe $(\mu \mathrm{g} / \mathrm{mL})$

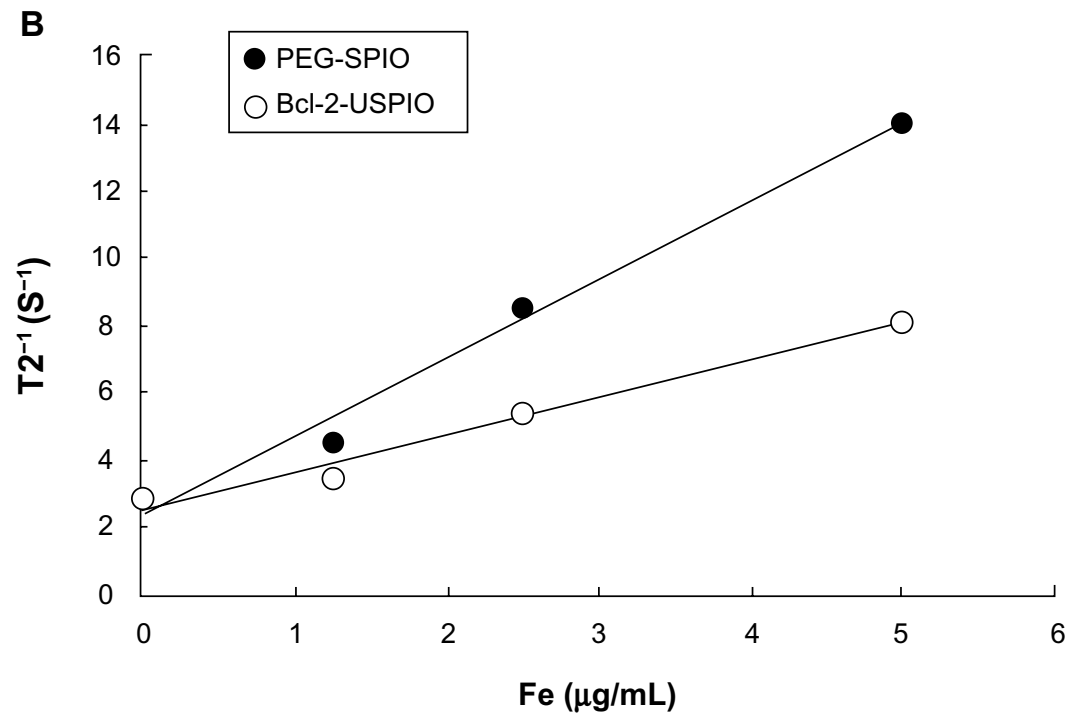

Figure 4 (A) T2-weighted MRI of PEG-USPIO or Bcl-2-USPIO diluted with DI water, in tubes with increasing iron concentrations. (B) I/T2 versus iron concentration of PEG-USPIO or BCl-2-USPIO and analyzed by linear equation. ${ }^{2}$

Notes: ${ }^{a}$ (PEG-USPIO: $\left.y=2.3236 x+2.3863, R 2=0.9879 ; B c I-2-U S P I O: ~ y=1.0858 x+2.5726, R 2=0.9796\right)$

Abbreviations: Bcl, B-cell lymphoma; Bcl-2-USPIO, Bcl-2-functionalized ultrasmall superparamagnetic iron oxide; DI, deionized; Fe, iron; MRI, magnetic resonance imaging: PEG-USPIO, polyethylene glycol-coated ultrasmall superparamagnetic iron oxide.

coating helped the nanoparticles to penetrate the cell membrane, as mentioned before; however, consistent with the results of the Bcl-2 expression assay, the degree of improvement was not significant. On the other hand, the results also indirectly verified that our antibody was efficiently bound to the terminal carboxyl after the carboxylation reaction.

\section{In vitro $\mathrm{PB}$ staining and in vivo immunohistochemistry and MRI of $\mathrm{Bcl}$-2-USPIO-labeled islet cells}

Before in vivo monitoring, we assessed the labeling efficiency of the primary rodent islet cells in vitro. Figure $6 \mathrm{~A}$ shows the primary mouse islet cells before USPIO labeling. Figure 6B 

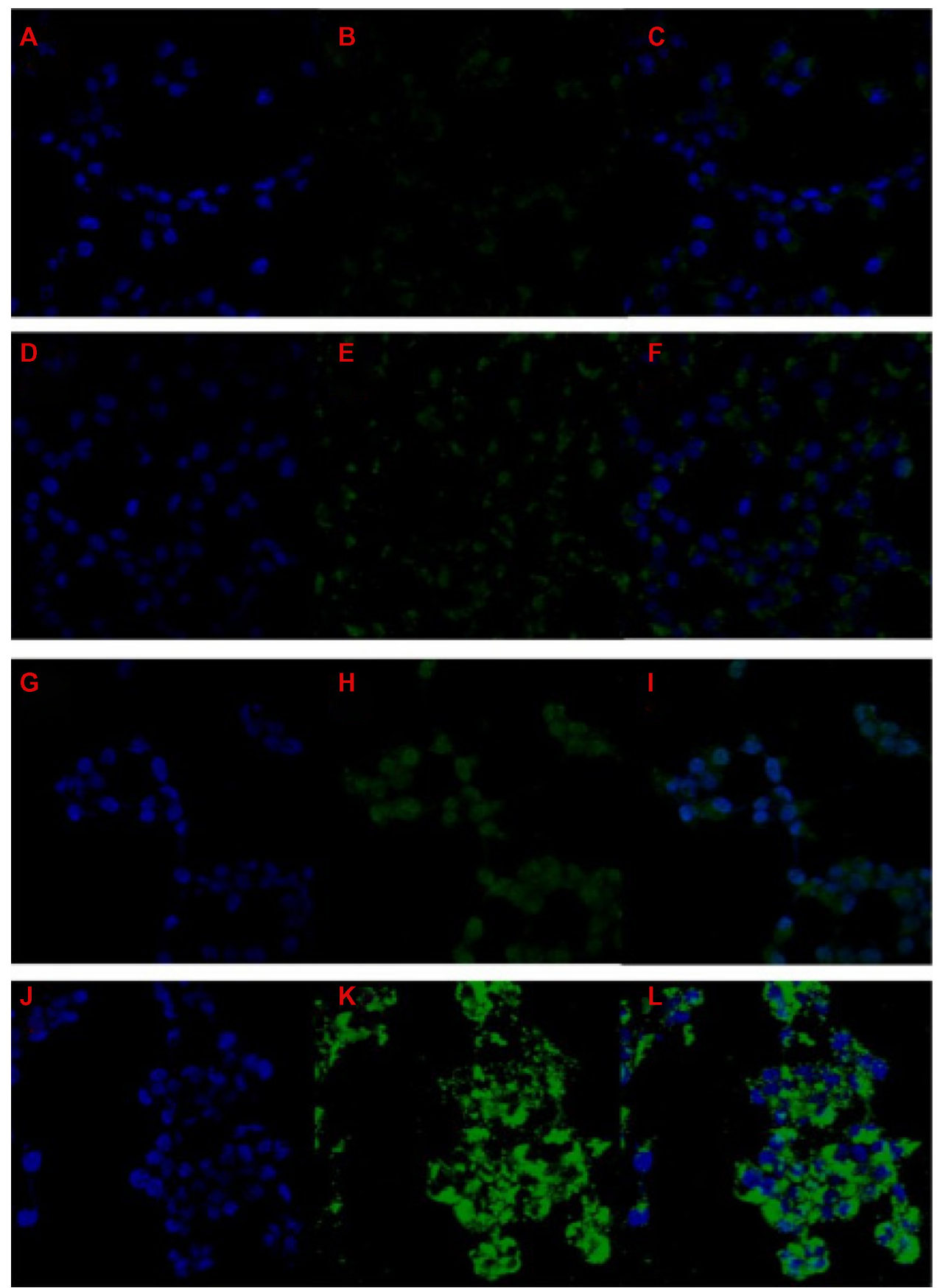

Figure 5 Comparison of the labeling efficiency of functionalized or nonfunctionalized nanoparticles at various iron concentrations.

Notes: INS-I cells were cultured with nonfunctionalized PEG-USPIO for 24 hours at $10 \mu \mathrm{g} / \mathrm{mL}$ (iron concentration). The cell nucleus was stained by DAPI (A). The nanoparticles were observed by FITC (B). The merged (A and B) image is shown in (C). INS-I cells were also cultured with functionalized USPIO for 24 hours at $10 \mu \mathrm{g} / \mathrm{mL}$ (D-F); $30 \mu \mathrm{g} / \mathrm{mL}$ (G-I); and $50 \mu \mathrm{g} / \mathrm{mL}$ iron concentration (J-L).

Abbreviations: DAPI, 4',6-diamidino-2-phenylindole; FITC, fluorescein isothiocyanate; INS, insulinoma; PEG-USPIO, polyethylene glycol-coated ultrasmall superparamagnetic iron oxide; USPIO, ultrasmall superparamagnetic iron oxide.

demonstrates that the Bcl-2-USPIOs tagged/surrounded the islet cells tightly and evenly. Figure $6 \mathrm{C}$ and $\mathrm{D}$ displays amplified intact islet cells labeled with the Bcl-2-USPIOs (stained as blue dots). In our in vivo models, Bcl-2-USPIO also displayed good beta-cell labeling properties, verified by immunohistochemistry (Figure 6E-H). It is interesting to note that our Bcl-2-USPIO also could mark islet cells at the transplantation area. The insulin stain displayed the rough graft region under the capsule of the left kidney, while the PB staining of the nanoparticles marked the transplanted islets more individually.

As Figure 7 shows, the signal from the grafts faded gradually from day 1 to 21 post-transplantation, which is in 

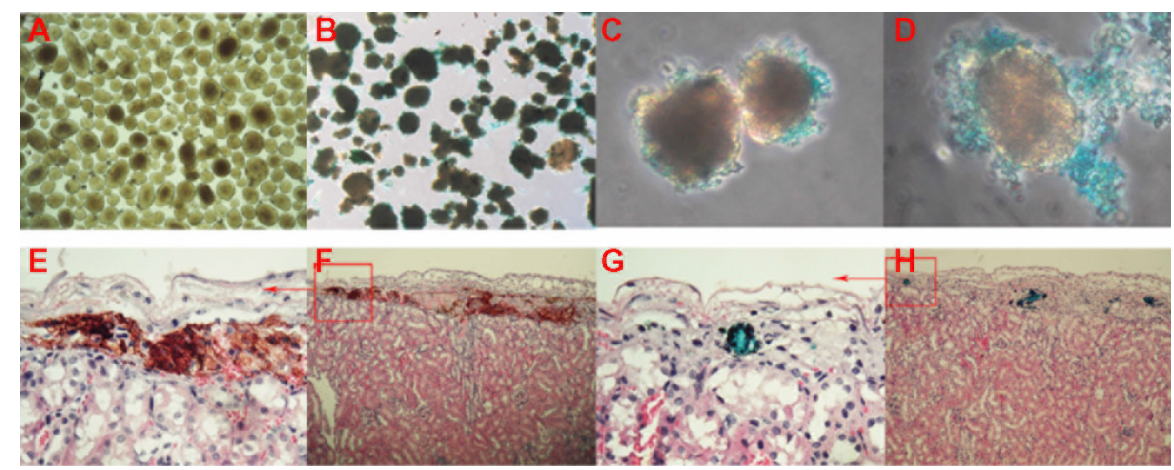

Figure $6 \mathrm{Bcl}$-2-USPIO clearly attached to the primary rodent islet cell clusters in vivo and in vitro.

Notes: The purified mouse islets (A). The islet is surrounded and labeled by Bcl-2-USPIO (B). Amplified picture of the labeled islets (C and D). The immunohistochemistry assay $(\mathbf{F}$ and $\mathbf{H})$ of the transplanted islets stained by insulin $(\mathbf{F})$ and Prussian blue $(\mathbf{H})$. The amplified pictures $(\mathbf{E}$ and $\mathbf{G})$ of the top left corner of images $(\mathbf{F}$ and $\mathbf{H})$, respectively.

Abbreviations: $\mathrm{Bcl}$, B-cell lymphoma; Bcl-2-USPIO, Bcl-2-functionalized ultrasmall superparamagnetic iron oxide.

accordance with the immune rejection period of the grafts. Further, the variation of Fe concentration certainly influenced the signal intensity of the tracer. We noted that the dose of 30 $\mu \mathrm{g} / \mathrm{mL}$ was too high for labeling of the 150 rodent islet cells, causing a hypointense signal at the beginning (Figure 7A and B). However, as Figure 7C, F, and I shows, long-term monitoring could not be achieved since the signals disappeared in a short time at the dose of $10 \mu \mathrm{g} / \mathrm{mL}$. This obstacle requires further research. We also note that there was some signal elevation (a bright white margin) around the transplant
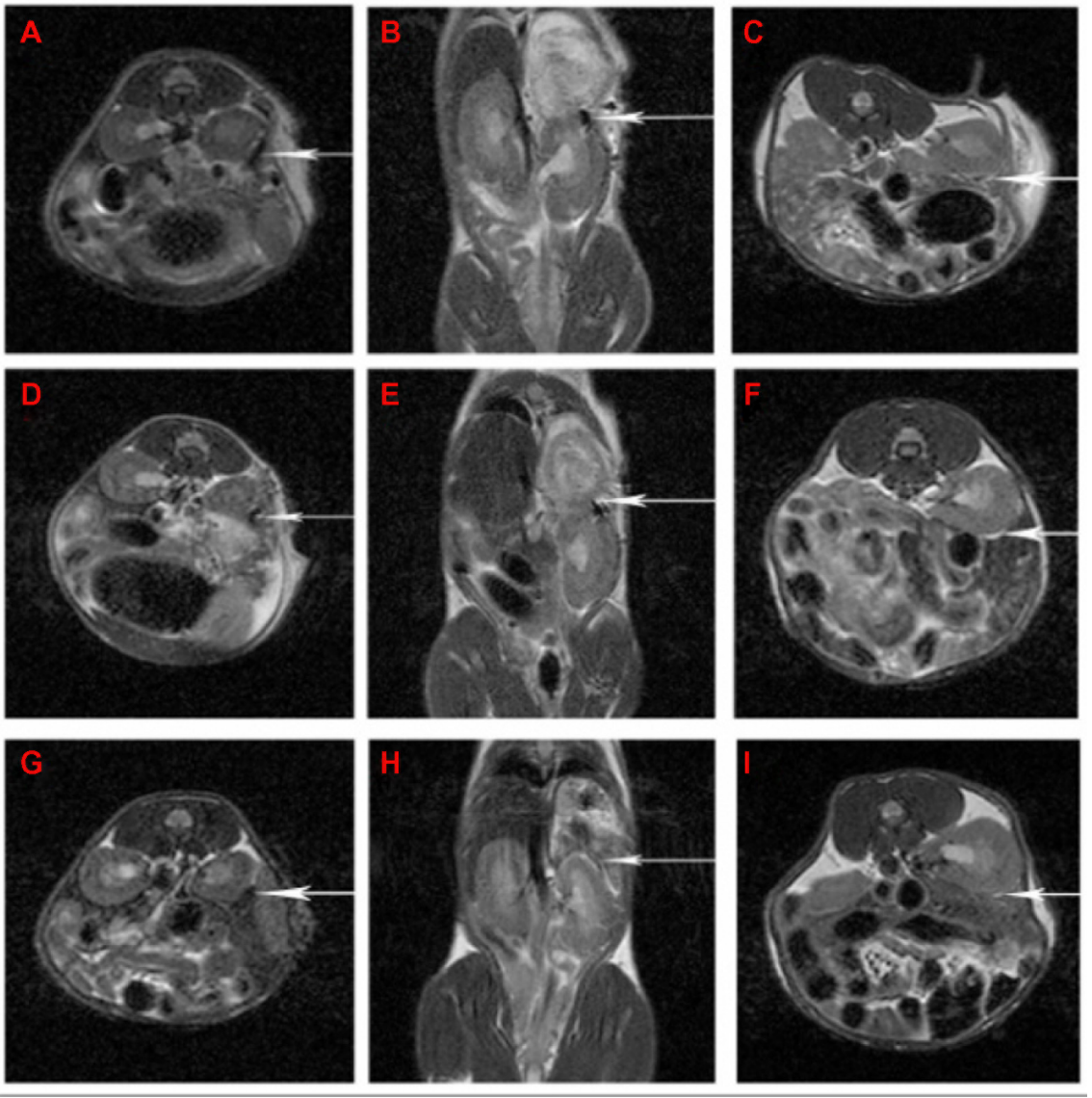

Figure 7 The MRI scanning pictures of Bcl-2-USPIO-labeled islet cell clusters after allotransplantation at the same position.

Notes: The islets were labeled with Bcl-2-USPIO at $30 \mu \mathrm{g} / \mathrm{mL}(\mathbf{A}, \mathbf{B}, \mathbf{D}, \mathbf{E}, \mathbf{G}$, and $\mathbf{H})$ or $10 \mu \mathrm{g} / \mathrm{mL}(\mathbf{C}$, F, and I) iron concentration, respectively. As the arrow pointed, the pictures present the signal intensity change of the transplanted islets under the left renal capsule on day I (A-C), day 7 (D-F), and day 2 I (G-I) post-transplantation. Abbreviations: Bcl, B-cell lymphoma; Bcl-2-USPIO, Bcl-2-functionalized ultrasmall superparamagnetic iron oxide; MRI, magnetic resonance imaging. 
site (Figure 7C, F, and I). This was likely a result of inflammatory liquid infusion, which is a common phenomenon found in transplantation surgery.

\section{Discussion}

During the past decades, several physical and chemical approaches, such as the organic colloid method, ${ }^{22}$ reverse micelle method, ${ }^{23}$ interfacial coprecipitation method, ${ }^{24}$ the solvothermal reaction, ${ }^{25}$ high-temperature hydrolysis reaction, ${ }^{26}$ and the thermal decomposition or reduction method, ${ }^{27}$ have been well used to improve the properties of nanoparticles. Some of these have partly handled the problems of broad size distributions, irregular crystallite shape, and poor crystallization. Nevertheless, the difficulties of requiring expensive and toxic reagents as well as harsh reaction conditions still exist. Zhao et $\mathrm{al}^{28}$ reported that metal oxide nanomaterials, which occur in smoke from fires and which come from the direct combustion of a methanol solution of $\mathrm{Fe}(\mathrm{acac}) 3$, could interact with the air-blood barrier in the human lung and cause damage. In our current study, we developed a succinct USPIO synthesis route using $\mathrm{FeSO}_{4}$ as precursor, avoiding the use of a toxic reagent, and successfully coated the surface of the Fe core with an amphiphilic polymer (OE-PEG-OH or OE-PEG$\mathrm{COOH})$. PEG was previously proved to effectively reduce plasma protein binding, to delay clearance by the reticuloendothelial system, and to increase particle circulation times. ${ }^{29-31} \mathrm{PEG}$ is also poorly immunogenic and antigenic and acts as an excellent repellent for biomolecules. ${ }^{32}$ Our novel nanoparticles showed uniform distribution in water, and the average hydrodynamic size was around $28 \mathrm{~nm}$. The saturation magnetization intensity of our PEG-USPIO was about $38 \mathrm{emu} / \mathrm{g}$, which is similar to that of the commercial product Feridex $(41 \mathrm{emu} / \mathrm{g}),{ }^{5}$ presenting good magnetic behavior.

The prepared PEG-USPIO is a kind of nontargeted nanoparticle, in other words, it had no "attraction" to cells; increasing the attraction requires a specific probe to the targeted cells and a suitable link between them. Jia et al reported they connected an Fe core and other probes through the two carboxyl groups of HOOC-PEG-COOH. However, their experiments revealed that HOOC-PEG-COOH could cross-link the Fe(acac) 3 molecules (the core of the nanoparticle), with the aid of oleylamine, to form gels, ${ }^{33}$ which easily induced nanoparticle aggregation. This problem is inevitable when using polymers with the same terminal groups. Instead, as we presented here, using amphiphilic polymers (OE-PEG-OH) solved this problem. The hydrophobic part of OE-PEG-OH could wrap the oily Fe core, while the other hydrophilic end was left outside to prevent the cross-linking of the nanoparticles. With the unique $\mathrm{COOH}$ group outside, the connection of the probes and nanoparticles was more straightforward.

The biological effect of internalizing the $\mathrm{Fe}$ in the nanoparticles is another key point for clinical application. Although it was previously reported that no clinical signs of toxicity were observed during or after Fe oxide administration of large doses of USPIO (30 mg Fe/ $\mathrm{kg}$ vs $5.6 \mathrm{mg} \mathrm{Fe} / \mathrm{kg}$ body weight) ${ }^{34}$ the safe dosage range of these nanoparticles is still uncertain. Berry et $a l^{35}$ reported that human fibroblast exposed to $50 \mu \mathrm{g} / \mathrm{mL}$ of SPIOs for 48 hours showed an increase in apoptosis and cell death, aberrations in cell morphology, and a decrease in cell motility. Papanikolaou and Pantopoulos ${ }^{36}$ reported an increase of intracellular free ferrous Fe induced cellular reactive oxygen species (ROS) production through Haber-Weiss-Fenton reactions, and ultimately caused lipid peroxidation and deoxyribonucleic (DNA) damage, which may cause cell apoptosis and death. From our results, we also noticed the side effects of the nanoparticle treatment in the beta-cells, and we consider the distinct "boundary" dose of our USPIO may be $30 \mu \mathrm{g}$ / $\mathrm{mL}$. When the dosage is higher than this, the function of the beta-cells was obviously weaker, and the apoptosis increased rapidly (Figure 3). Also, the insulin secretion under high glucose stimulation declined quickly in association with high USPIO dosage. Although our "boundary" is lower than in other reports, the different cell lines and nanoparticles may be the possible reasons for the dose variation. We consider it is better to set the limit at a relatively lower dosage at the beginning of clinical application.

Based on the lack of a specific biomarker and the narrow safe dosage range of the nanoparticles, our strategy is to maximize cell labeling at lower Fe concentration, without influencing the function of the labeled cells. Our experiments indicate that the $\mathrm{Bcl}-2$ monoclonal antibody combination is a feasible choice. Although the Bcl-2 expression increase was limited, it still revealed that with the addition of the antibody, more USPIOs were uptaken by INS-1 cells compared with untagged USPIO (Figure 5). The labeling efficiency was also confirmed in vivo (Figure 6). However, we found the content of accumulated Fe in the grafts to be a little bit lower than expected. Smirnov et al reported ${ }^{37}$ that $\mathrm{PB}$ staining stained only a fraction $\left(\mathrm{Fe}^{3+}\right)$ of the studied particles $\left(\mathrm{Fe}^{3+}\right.$ and $\left.\mathrm{Fe}^{2+}\right)$ and that some labeled cells were probably undetected, but detectable by MRI. We think this might be the explanation of our results. It was also a little difficult to thoroughly 
label the primary islet cell clusters because these contained approximately 2,000 cells per islet cluster, ${ }^{38}$ and it is improbable to label every single cell in the cluster. However, we were delighted to demonstrate that Bcl-2 functionalized USPIO nanoparticles were efficient for beta-cell labeling within the safe dosage range, both in vitro and in vivo. In our experiments, we also noticed a hypointense signal appeared when the Fe concentration exceeded $10 \mu \mathrm{g} / \mathrm{mL}$ in vitro (Figure $4 \mathrm{~A}$ ) and in vivo (Figure 7A and B). The excessive concentration of the contrast agents or the inflammatory liquid infusion might be the explanation for this. This obstacle to long-term monitoring in vivo with suitable dosages of nanoparticles, needs to be studied further.

It is worthwhile to note that our synthesis route has strong flexibility. Based on the active terminal carboxyl group, we could easily replace the Bcl-2 antibody with other specific cell tracing probes. Actually, a nonspecific labeling strategy was suitable for islet cell tracing because we could label the islets in vitro before transplantation. However, for visualization of the in situ cells, a specific probe is a prerequisite. Our flexible synthesis approach could satisfy this request. Limitations of the current study were that we did not evaluate the mechanism of USPIO uptake or the immune response to the USPIOs. It is worth further multistage exploration to confirm that the MRI signal is generated specially from the labeling agent retained within the cells of interest, and that this is not degenerated with time or transferred to other cells.

\section{Conclusion}

In this study, Bcl-2-functionalized USPIO nanoparticles were synthesized succinctly with nontoxic agents, the USPIO nanoparticles were coated with amphiphilic polymers and had good distribution and biocompatibility properties. The novel nanoparticle was capable of efficient labeling of beta cells and rodent islet cells in vitro and enabled MRI of the islets in vivo. Further, our flexible synthesis route makes it possible to replace the targeted tracer probe as required. These results strongly suggest that Bcl-2-USPIO may serve to be a promising contrast enhancement agent for MRI of transplanted islets or other cells in future.

\section{Acknowledgments}

This study was supported by grants from the National Natural Science Foundation of China (grant numbers: 81100549, 81172158,81001094 , and 81272332) and the Ministry of Science and Technology of the People's Republic of China (grant number 2007AA02Z476).

\section{Disclosure}

The authors report no conflicts of interest in this work.

\section{References}

1. Tong L, Zhao M, Zhu S, Chen J. Synthesis and application of superparamagnetic iron oxide nanoparticles in targeted therapy and imaging of cancer. Front Med. 2011;5(4):379-387.

2. Mornet S, Vasseur S, Grasset F, Duguet E. Magnetic nanoparticle design for medical diagnosis and therapy. J Mater Chem. 2004;14: 2161-2175.

3. Gaglia JL, Guimaraes AR, Harisinghani M, et al. Noninvasive imaging of pancreatic islet inflammation in type 1 A diabetes patients. $J$ Clin Invest. 2011;121(1):442-445.

4. Taylor A, Wilson KM, Murray P, Fernig DG, Lévy R. Long-term tracking of cells using inorganic nanoparticles as contrast agents: are we there yet? Chem Soc Rev. 2012;41(7):2707-2717.

5. Lodhia J, Mandarano G, Ferris Nj, Eu P, Cowell S. Development and use of iron oxide nanoparticles (Part 1): Synthesis of iron oxide nanoparticles for MRI. Biomed Imaging Interv J. 2010;6(2):e12.

6. Zhang B, Jiang B, Chen Y, et al. Detection of viability of transplanted beta cells labeled with a novel contrast agent - polyvinylpyrrolidonecoated superparamagnetic iron oxide nanoparticles by magnetic resonance imaging. Contrast Media Mol Imaging. 2012;7(1):35-44.

7. Oh CS, Kohanim S, Kong FL, et al. Sulfonylurea receptor as a target for molecular imaging of pancreas beta cells with (99 m)Tc-DTPAglipizide. Ann Nucl Med. 2012;26(3):253-261.

8. Clark PB, Gage HD, Brown-Proctor C, et al. Neurofunctional imaging of the pancreas utilizing the cholinergic PET radioligand [18F]4-fluorobenzyltrozamicol. Eur J Nucl Med Mol Imaging. 2004;31(2):258-260.

9. Goland R, Freeby M, Parsey R, et al. 11C-dihydrotetrabenazine PET of the pancreas in subjects with long-standing type 1 diabetes and in healthy controls. J Nucl Med. 2009;50(3):382-389.

10. Zhang B, Yang B, Zhai C, Jiang B, Wu Y. The role of exendin-4conjugated superparamagnetic iron oxide nanoparticles in beta-celltargeted MRI. Biomaterials. 2013;34(23):5843-5852.

11. Krpetić Z, Saleemi S, Prior IA, Sée V, Qureshi R, Brust M. Negotiation of intracellular membrane barriers by TAT-modified gold nanoparticles. ACS Nano. 2011;5(6):5195-5201.

12. Wunderbaldinger P, Josephson L, Weissleder R. Tat peptide directs enhanced clearance and hepatic permeability of magnetic nanoparticles. Bioconjug Chem. 2002;13(2):264-268.

13. Bulte JW, Douglas T, Witwer B, et al. Magnetodendrimers allow endosomal magnetic labeling and in vivo tracking of stem cells. Nat Biotechnol. 2001;19(12):1141-1147.

14. Matuszewski L, Persigehl T, Wall A, et al. Cell tagging with clinically approved iron oxides: feasibility and effect of lipofection, particle size, and surface coating on labeling efficiency. Radiology. 2005;235(1): $155-161$.

15. Wilhelm C, Gazeau F. Universal cell labelling with anionic magnetic nanoparticles. Biomaterials. 2008;29(22):3161-3174.

16. Kim SJ, Nian C, Widenmaier S, McIntosh CH. Glucose-dependent insulinotropic polypeptide-mediated up-regulation of beta-cell antiapoptotic Bcl-2 gene expression is coordinated by cyclic AMP (cAMP) response element binding protein (CREB) and cAMP-responsive CREB coactivator 2. Mol Cell Biol. 2008;28(5):1644-1656.

17. Rabinovitch A, Suarez-Pinzon W, Strynadka K, et al. Transfection of human pancreatic islets with an anti-apoptotic gene (bcl-2) protects beta-cells from cytokine-induced destruction. Diabetes. 1999;48(6): $1223-1229$.

18. Iwahashi H, Hanafusa T, Eguchi Y, et al. Cytokine-induced apoptotic cell death in a mouse pancreatic beta-cell line: inhibition by Bcl-2. Diabetologia. 1996;39(5):530-536.

19. Liang X, Wang X, Zhuang J, Chen Y, Wang D, Li Y. Synthesis of nearly monodisperse iron oxide and oxyhydroxide nanocrystals. Adv Funct Mater. 2006;16(14):1805-1813. 
20. Huang H, Xie Q, Kang M, et al. Labeling transplanted mice islet with polyvinylpyrrolidone coated superparamagnetic iron oxide nanoparticles for in vivo detection by magnetic resonance imaging. Nanotechnology. 2009;20(36):365101.

21. Bulstra SK, Drukker J, Kuijer R, Buurman WA, van der Linden AJ. Thionin staining of paraffin and plastic embedded sections of cartilage. Biotech Histochem. 1993;68(1):20-28.

22. Park J, Lee E, Hwang NM, et al. One-nanometer-scale size-controlled synthesis of monodisperse magnetic iron oxide nanoparticles. Angew Chem Int Ed Engl. 2005;44(19):2873-2877.

23. Lee Y, Lee J, Bae CJ, et al. Large-scale synthesis of uniform and crystalline magnetite nanoparticles using reverse micelles as nanoreactors under reflux conditions. Adv Funct Mater. 2005;15(3):503-509.

24. Tao K, Dou H, Sun K. Facile interfacial coprecipitation to fabricate hydrophilic amine-capped magnetite nanoparticles. Chem Mater. 2006;18(22):5273-5278.

25. Gao L, Wu J, Lyle S, Zehr K, Cao L, Gao D. Magnetite nanoparticle-linked immunosorbent assay. J Phys Chem C. 2008;112(44): 17357-17361

26. Zhong LS, Hu JS, Liang HP, Cao AM, Song WG, Wan LJ. Self-assembled 3D flowerlike iron oxide nanostructures and their application in water treatment. Adv Mater. 2006;18(18):2426-2431.

27. Li Y, Afzaal M, O’Brien P. The synthesis of amine-capped magnetic (Fe, Mn, Co, Ni) oxide nanocrystals and their surface modification for aqueous dispersibility. J Mater Chem. 2006;16:2175-2180.

28. Zhao N, Ma W, Cui Z, Song W, Xu C, Gao M. Polyhedral maghemite nanocrystals prepared by a flame synthetic method: preparations, characterizations, and catalytic properties. ACS Nano. 2009;3(7): 1775-1780.

29. Li Z, Wei L, Gao MY, Lei H. One-pot reaction to synthesize biocompatible magnetite nanoparticles. Adv Mater. 2005;17(8):1001-1005.
30. Hu FQ, Wei L, Zhou Z, Ran YL, Li Z, Gao MY. Preparation of biocompatible magnetite nanocrystals for in vivo magnetic resonance detection of cancer. Adv Mater. 2006;18(19):2553-2556.

31. Liu D, Wu W, Ling J, Wen S, Gu N, Zhang X. Effective PEGylation of iron oxide nanoparticles for high performance in vivo cancer imaging. Adv Funct Mater. 2011;21(8):1498-1504.

32. Dubertret B, Skourides P, Norris DJ, Noireaux V, Brivanlou AH, Libchaber A. In vivo imaging of quantum dots encapsulated in phospholipid micelles. Science. 2002;298(5599):1759-1762.

33. Jia Q, Zeng J, Qiao R, et al. Gelification: an effective measure for achieving differently sized biocompatible Fe3O4 nanocrystals through a single preparation recipe. J Am Chem Soc. 2011;133(48):19512-19523.

34. Wen S, Liu DF, Liu Z, et al. OxLDL-targeted iron oxide nanoparticles for in vivo MRI detection of perivascular carotid collar induced atherosclerotic lesions in ApoE-deficient mice. J Lipid Res. 2012;53(5): 829-838.

35. Berry CC, Wells S, Charles S, Aitchison G, Curtis AS. Cell response to dextran-derivatised iron oxide nanoparticles post internalisation. Biomaterials. 2004;25(23):5405-5413.

36. Papanikolaou G, Pantopoulos K. Iron metabolism and toxicity. Toxicol Appl Pharmacol. 2005;202(2):199-211.

37. Smirnov P, Lavergne E, Gazeau F, et al. In vivo cellular imaging of lymphocyte trafficking by MRI: a tumor model approach to cell-based anticancer therapy. Magn Reson Med. 2006;56(3):498-508.

38. Barnett BP, Ruiz-Cabello J, Hota P, et al. Use of perfluorocarbon nanoparticles for non-invasive multimodal cell tracking of human pancreatic islets. Contrast Media Mol Imaging. 2011;6(4):251-259.
International Journal of Nanomedicine

\section{Publish your work in this journal}

The International Journal of Nanomedicine is an international, peerreviewed journal focusing on the application of nanotechnology in diagnostics, therapeutics, and drug delivery systems throughout the biomedical field. This journal is indexed on PubMed Central, MedLine, CAS, SciSearch $\AA$, Current Contents ${ }^{\circledR} /$ Clinical Medicine,

\section{Dovepress}

Journal Citation Reports/Science Edition, EMBase, Scopus and the Elsevier Bibliographic databases. The manuscript management system is completely online and includes a very quick and fair peer-review system, which is all easy to use. Visit http://www.dovepress.com/ testimonials.php to read real quotes from published authors. 